\title{
Psychoanalysis and Noir's American Nightmare
}

\author{
Albena Vladimirova Zahariev, ${ }^{*}$ Clark Honors College
}

\begin{abstract}
Sigmund Freud's work on psychoanalysis offers relief from the void left by World War II and accompanying frustrations with the American Dream. In acknowledgement of Freud's exposition of the danger of repression, noir permits the articulation of impulses repressed in the interest of war efforts through a narrative that functions as a nightmarish psychological expression. Furthermore, noir engages with Freud's work on unconscious motives to creatively and psychoanalytically explore potential motives behind behavior considered disordered according to American principles - such as crime and self-destructive behavior. Noir demonstrates the strong influence of a disordering environment on a protagonist's actions and motives, and promotes the value of a critically thinking "detective" who can explain disorder, encouraging the audience to fill this role themselves. Noir's demand for active audience interpretation works in contrast to World War II war efforts, which demanded complete faith in government propaganda. In this way, noir inspires the audience to themselves challenge the feasibility of achieving the American Dream through an American work ethic, the hardboiled tradition, the ideology of individualism, and American values and traditions as a whole.
\end{abstract}

If necessity is the mother of all invention, then noir sprouted organically out of the need to process the psychological stress left behind by World War II and the accompanying realization of the widespread unattainability of the American Dream. Within noir, psychoanalysis functions most prolifically through the relationships between the protagonist, disordering environment, and detective. Their interactions illuminate the dramatic impression of outside forces on an individual's ability to achieve the American Dream. Noir casts these roles with creativity within a narrative presented as a raw, pulpy, nightmarish psychological expression in order to inspire and invite psychoanalytical interpretation by the audience. By toying with Sigmund Freud's work on motives and repression, noir both allows its audience a cathartic outlet to indulge previously repressed stress and impulses, as well as empowers its audience to approach disorder with critical thinking.

Post-war disillusionment sets the context for the great psychological stress noir seeks to address. American nationalistic attitudes during World War II demanded great dedication, hard work, and sacrifice for the sake of the war effort. Unwavering faith in the strength and value of the United States made way for criticism of the country. Soldiers returned home to find working women and minorities, bringing a greater focus onto social justice issues and the viability of the American Dream. Women refused to give up their newfound independence, leading to a sharp uptick in the divorce rate, which in combination with the great loneliness of increasing industrialization, contrasted the tight unity of the country during the war. Disillusionment

\footnotetext{
*Albena Vladimirova Zahariev is a freshman in the Clark Honors College at the University of Oregon. Please direct correspondence to azahariev17@gmail.com.
} 
reigned in the wake of the war, and America challenged the value of the individual. In "The Dark Mirror: Sex, Dreams, and Psychoanalysis," Nicholas Christopher describes the role of noir in post-war America by quoting James Greenberg, saying that "film noirs were movies about adults, made for adults who had just been through a war" (88). World War II and a strained American Dream set the precedent for Freud's work to flourish in the United States by aiding Americans in processing post-war disillusionment.

The rise of Freud's popularity during the noir period introduced psychoanalysis as a means to process anxieties about the failing American Dream, by investigating the disordering forces at the root of the failure. Noir's disorder manifests in the form of psychological stress, but also in crime, evil, and irrational destructive behavior; basically, in any behavior that contradicts the American Dream. Freud's psychoanalytic work helps elucidate disorder by probing into the motives behind disordered behavior. The media found such potential in his work that Freud received two significant deals to use his skills to entertain: one specifically citing psychoanalysis' role in crime, offering Freud $\$ 25,000$ to psychoanalyze two defendants in a sensational murder trial for the Chicago Tribune, and another offering Freud $\$ 100,000$ to help write a romantic screenplay for Hollywood Producer Samuel Goldwyn (Christopher 187-8). Freud declined both offers. Perhaps he had no desire for the media to sensationalize his work, and perhaps the media's lack of an academic respect for his work frustrated him, but these offers demonstrated a strong public demand and desire for psychological understanding. To further establish the connection between crime fiction and noir, Amy Yang examines literature's influence on formation of Freud's psychoanalytic theory. In "Psychoanalysis and Detective Fiction: A Tale of Freud and Criminal Storytelling," she discusses Edgar Allen Poe, who gave Freud the initial literary precedent for his work, and Sherlock Holmes, who provided Freud an analytic model. She explains how, in response, much criminal storytelling "embedded Freudian theories in subsequent forms, spinning the tales of crime into a journey into the human mind" (Yang 596). Although an amateurish adaptation of psychoanalysis, noir's detective narratives satisfy America's thirst for Freud's work by explaining crime through an exploration of the motives of the human mind behind it.

Freud's work underlies noir's functions in two primary ways. First, his work indicates a need to release repressed impulses, desires, and ideas. Americans at the time harbored a considerable volume of repressed impulses, especially considering the many freedoms, thoughts, and desires repressed in the interest of the war. In fact, the release of consumerist impulses unarticulated due to the war effort helps account for America's economic uptick following the war. Noir allows a similar release. In "Crime, Guilt, and Subjectivity in 'Film Noir,"” Winfried Fluck comments on how noir "permits the articulation of impulses that may still be considered 'extreme' but are nevertheless 'tempting"' (404). Christopher's article echoes this sentiment, saying that for the first time in American film, "Americans' sexual preoccupations, obsessions, and perversions are explicitly dealt with," $(89,191)$. Through femme fatales, damaged heroes, and the proliferation of dramatic violence, crime, and murder, noir acts out the greatest nightmares and desires of a nation faced with shifting gender roles, great loneliness, and a threatened American Dream. 
The film Double Indemnity, for example, indulges several of these nightmares and desires in order to provide the audience with a sense of release. In the film, femme fatale Phyllis Dietrichson manipulates Walter Neff, an insurance salesman, into assisting her in murdering her husband and staging the death as a train accident in order to make a "double indemnity" insurance claim. As a femme fatale, Phyllis indulges the audience's fantasies of a powerful, sexually expressive, and aggressive woman, while simultaneously articulating their fear of the repercussions of unleashing and being manipulated by such a woman. This allowed the audience to process anxieties about women's growing independence. Furthermore, Phyllis's scheme indulges the audience's fantasies of suspending moral inhibitions and selfishly staking out one's claim to a piece of the American Dream-a fantasy resulting from America's individualistic culture. By indulging this fantasy, Double Indemnity provides the audience a sense of release after being required to repress selfishness for the sake of WWII war efforts. Meanwhile, the film also articulates the nightmare of dealing with the anxiety of potentially being caught. Noir's indulgently pulpy and melodramatic elements reiterate Freud's stance on repression.

Secondly, Freud's work encourages an analysis of motive and the impact of the environment on the individual. After articulating and releasing America's repressed psychic material, noir began to ascertain the causes of disordered behavior. Psychoanalysis teases out the motives behind crime and otherwise disordered behavior that leads away from achieving the American Dream. In "Psychoanalysis and Detective Fiction: A Tale of Freud and Criminal Storytelling," Amy Yang alludes to psychoanalysis' role in displacing blame from the criminal: "it delved into the criminal's mind, teasing out the underlying driving force for murder, even if the criminal was not actively aware of it at the time of crime" (597). She continues, "in other words, it dislodged the notion of free will from the intent to commit crime" (Yang 597). Yang's argument thus prompts the question of the actual origins of the intent to commit crime. Rather than citing innate insanity, noir progressively moved towards considering the motivations behind psychotic action, typically recognizing the action as a reflection of the greater, cultural psyche.

"Gun Crazy," the short story by MacKinlay Kantor, demonstrates noir's inquisitiveness about the mind of a criminal. The story centers on Nelson Tare, a gun-obsessed boy who grows up to become a bank-robbing criminal. The story comes through the first-person perspective of his childhood friend, Dave. Dave's first-person perspective uniquely reveals the childhood history of the criminal, as well as encourages outside conjecture on his motivations and how his past may have shaped his personality. For example, as the narrator recounts meeting Nelson for the first time, he comments on his baby talk: "Nelson was only a month younger than I, it turned out, but he still talked a lot of baby talk. I think kids are apt to do that more when their parents don't talk to them much," (46). Shunned by his environment, Nelson turned to guns as a source of power. At the climactic end of the story, officers stood ready with machine guns attempting to capture Nelson. However, Sheriff Clyde Boston, who had known Nelson as a child, recounted a hunting trip in which Nelson was unable to shoot a rabbit despite his excellent marksmanship. Recognizing his unwillingness to shoot a soul, Clyde tackled Nelson to the ground, preventing further violence. Using memories of Nelson's past, Clyde recognizes Nelson as a fundamentally gentle person despite his criminal activity. "Gun Crazy" challenges the notion of the innately evil 
criminal, encouraging empathy from the audience and a closer look at the criminal as a person, with the suggestion that these individuals are merely misunderstood.

Noir sources an individual's motives and psychological well-being to their environment, supporting John Locke's philosophy of the tabula rasa, which means "blank slate," and refers to the philosophy that individuals start out as neither basically good nor basically evil, but as blank slates to be shaped by their environment. At the heart of the American Dream lies the issue of overcoming one's past and environment-what Mark Osteen refers to in his article, "Introduction: Film Noir and the American Dream," as the "ideology of individualism-the belief that personal effort enables one to determine one's own destiny and character" (2). Psychoanalysis in noir deals precisely with the issue of the individual versus their environment, bringing out an attitude of fatalism that directly contradicts the ideology of individualism behind the American Dream. According to the ideology of individualism, people who fail to achieve the American Dream fail because of their character and unwillingness to work hard. However, in noir, "the obstacles aren't merely character flaws; they are features of society," (Osteen 3). Culturally, this shifts the blame away from the criminal, and onto the external factors, sharply contrasting America's individualistic attitude. In this exploration of motives and repressed motives, Freud's work helps Americans absolve their guilt for failing to achieve the American Dream. As a system that delves into outside influences on the individual psyche, psychoanalysis appeals to noir's audience because it investigates the failure of the American Dream as a failure of the environment-not of the individual.

Noir ironically paints American values as one of the greatest obstacles to achieving the American Dream. As a manifestation of American values, the hard-boiled tradition provides noir's foundation in examining the validity of American values as a means of achieving the American Dream. The hard-boiled tradition reinforces the values embraced by the American Dream: roughness, independence, quickness, focus, etc. However, these values do not ensure the hard-boiled hero's success in a noir narrative, and instead frequently lead to the hero's failure. David Goodis' short story, "Professional Man," exemplifies the conflict underlying the American Dream. As a professional, hard-working, dignified, and well-liked individual, the American Dream promises Freddy Lamb success. Instead, his persistent obedience leads to his downfall when his boss orders Freddy to murder his girlfriend. Freddy must either sacrifice his integrity as a professional man or sacrifice a woman he has real feelings for. The cold, calculating individualism and detachment that permits Freddy to kill professionally, allows his boss to force Freddy to act against his own best interests. Freddy's predicament comments on the failure of the American Dream for the working man within an individualistic society. In an individualistic society, a man with a strong work ethic who devotedly serves his boss gets taken advantage of, not rewarded. The hard-boiled tradition redefines individualism - in this world, one needs to be selfish and break rules in order to succeed.

The American neo-noir film A Simple Plan illustrates the motivating role of the American Dream in crime through an exchange between Hank and his friend Lou. After stumbling upon a bag filled with money inside a crashed airplane, Lou exclaims, "It's the American Dream in a goddamn gym bag!” Hank replies, "You work for the American Dream. You don't steal it.” Hank 
feels conflicted at the notion of keeping the money and committing a crime - particularly one with a potential victim. However, the same American work ethic that gives him pause before taking money he did not earn also makes him hesitate before giving up such a grand opportunity. Unlike Lou, Hank recognizes the vigilance and patience that would be necessary to avoid getting caught, and ultimately rises to the challenge. Regrettably for Hank, the film features unfortunate event after unfortunate event, despite his best efforts to control the situation.

The hard-boiled hero's split consciousness and objectivity demonstrates another value America encourages but fails to reward. The hard-boiled detective fundamentally remains "professional" and able to objectively study and interact with his disordered environment without becoming swallowed by it. Being only human, many noir heroes fail at maintaining objective separation from their environment in favor of pursuing their own interests. For example, Nick Curran, the homicide detective from the neo-noir film Basic Instinct, gets sexually involved with his prime murder suspect. This of course leads to his undoing because the relationship leaves him vulnerable, despite his successful solving of the case. Jeff Baily, the private investigator featured in the film Out of the Past also develops a relationship with the woman he was hired to track down. After she betrays him, he is surprised to run into her again, and succinctly expresses the emotional separation he has learned to be crucial by telling her, "Just get out, will you? I have to sleep in this room." However, even when noir protagonists succeed at maintaining an objective detachment from their environments, they fail. Freddy Lamb, for example, maintains his professionalism and kills his girlfriend, but says goodbye to his profession through suicide. Philip Marlowe, of Raymond Chandler's novel The Big Sleep, also remains professional. Unlike Nick Curran, he resists his suspects' seduction attempts, establishing him as a more powerful figure in the narrative than the incredibly wealthy characters he investigates. Yet even though he successfully maintains separation from his environment, in the end he remains a lonely, emotionally repressed man in an environment he condemns.

The protagonist's separation from his environment mimics psychoanalysis' distinction between the patient and his environment in order to explore the environment's effect on the psyche. Psychoanalysis recognizes the patient as distinct from his environment. However, psychoanalysis also acknowledges the environment's inevitable impression on the individual. The hard-boiled hero's attempts to stay separate from his environment not only will most likely fail, but the attempts breed repressed emotions, thoughts, and impulses. Noir's psychological approach highlights the impossibility of a psychologically secure, emotionally fulfilled, successful hard-boiled hero, proving the logical fallacy of achieving the American Dream through hard-boiled values.

Psychoanalysis functions in noir through three roles: the protagonist, the disordering environment, and the "detective" role that administers or encourages psychoanalysis. These roles play out most naturally and obviously in crime narratives, allowing the audience to burrow into the motives of a criminal. The criminal, frequently functioning as the protagonist, elicits empathy. By casting the everyday citizen (as opposed to a gangster) as the criminal, noir invites 
viewers to identify with the criminal, prompting questions of moral responsibility and opening an examination of the motives and environment that lead to crime. The roles of the protagonist and disordering environment reaffirm the existence of forces beyond the protagonist's control that dictate his actions. The existence of a detective role unveils a figure that can clarify disorder. In "Why They Went Bad: Criminology in Crime Films," Nicole Rafter supports this idea by asserting that crime films grant an explanation for crime. Clyde, the sheriff from "Gun Crazy," takes a psychological interest in Nelson that helps explain his disordered behavior and present him as a more sympathetic character. Yang well articulates the role of psychoanalysis in crime solving, contending that Freud's work introduces an understanding of the unconscious as a valuable aid in crime solving (600). This detail proves particularly handy in entertainment, because, as Yang maintains, readers now, in addition to plot, want to understand the psyche of the criminal (597). Philip Marlowe, of Raymond Chandler's The Big Sleep, exemplifies the traditional, hard-boiled noir private investigator that uses his separation from the environment to understand and predict disordered human behavior. By anticipating that Carmen would attempt to kill him for refusing sex with her - and thus must have killed Regan for the same reason - Marlowe reveals a predictability and sense of order to otherwise inexplicable behavior. While noir may present crime as irremediable, noir crime films affirm that there are certain individuals equipped to decipher and deal with crime - sense hides behind disorder, and psychoanalysis helps reveal it.

As a creative genre, noir casts these roles creatively, sometimes stepping outside the traditional crime narrative. The noir may cast other characters (rather than the city) as the disordering environment, or may cast a psychiatrist, layperson, or even the audience as the detective, but in any case these roles facilitate a fatalistic investigation of the impact of the environment on the protagonist. For example, the neo-noir film Mulholland Drive appears to present entirely senseless disorder in a series of seemingly unrelated vignettes. The film appears to feature only a disordering environment and flawed protagonist-lacking the third role of a detective. In actuality, the film positions the audience to act as the detective and make sense of the twisting byzantine narrative. Without hope of interpretation, the film would simply be a horror film - the presence of a detective defines the noir genre.

Osteen submits a counterargument to the idea of perceiving noir though a psychoanalytic perspective. He argues that film noir questions "whether anyone - whether detective, war veteran or homeless woman - can truly reinvent him or herself; by questioning whether new consumer products and technologies such as fast cars can really liberate us; and by raising a skeptical eyebrow at the midcentury faith in psychoanalysis and the therapeutic ethos that supports it" ("Introduction" 2). However, noir's use of psychoanalysis does not intend to facilitate self-reinvention as much as catharsis - a release of repressed emotions and an acknowledgement of one's own shortcomings, as well as an attempt to explain them. As Osteen argues, psychoanalysis fails to offer an effective path to reinvention - and not because of the shortcomings of psychoanalysis, but because psychoanalysis reveals fault in the environment and in American culture. Reinvention, more than anything, reflects an ethic of the American Dream -the idea of overcoming one's environment and flaws. Of course, looking for liberation and growth in a destructive environment is bound to be fruitless, and as noir reveals, attempts 
to resist the environment are exercises in futility. Noir may darkly reinforce hopelessness, but at least it uses psychoanalytic ideas to seek answers. Noir and neo-noir remain popular today because pessimistic, "intellectual" attitudes continue to prevail today.

Osteen raises a further counterargument against a psychoanalytic approach by suggesting that a cultural one serves more appropriately. Osteen points out how noir focuses obsessively on psychic disorder and how noir films bubble with cultural anxiety beneath their surface ("Introduction" 11, 14). While this might appear to call for a psychoanalytic approach, Osteen claims that his "approach is less psychoanalytic than cultural - an effort to chart noir's political unconscious" ("Introduction" 14). Noir lays its flawed characters' motivations on the table, exposing the uncontrollable influence of the environment on characters' psyches. Considering this, Osteen's reach for a cultural frame of reference towards understanding noir appears logical, because if noir emphasizes the influence of the environment, a cultural examination of the environment as a commentary on American culture looks tempting. While noir springboards off a flawed culture and its resulting frustrations - and does provide cultural commentary - noir's fatalistic attitude transcends frustrations with the American Dream.

Noir portrays its environments far too creatively and inventively to accurately reflect American culture; noir psychoanalytically addresses the "cultural anxiety" Osteen references by toying with the causes of anxiety more broadly. For example, while the film Gaslight might culturally comment on the necessity for greater agency for women within married relationships, the film explores psychology more broadly. The film coined the psychological term "gaslighting," which refers to a form of mental abuse in which the abuser manipulates the victim into doubting their own reality. The idea of "gaslighting" references the phenomenon of female hysteria, providing an alternative explanation to apparently irrational female behavior, rather than accusations of hysteria. Although Freud had an unfortunately inadequate understanding of women, and elaborated on hysteria as a legitimate diagnosis, he approached its diagnosis through its causes rather than its symptoms, which led to a reduction and eventual abandonment of the diagnosis (Micale). Had Paula been traditionally "diagnosed" by her behavior rather than its causes - particularly after her outburst at her friend's musical gathering - she certainly would have been diagnosed with hysteria. The psychoanalytic approach the film takes reveals the bigger picture of what caused her behavior - her abusive, gaslighting husband. Certainly noir reflects the anxieties of its cultural and historical contexts, but it also takes these anxieties a step further. The domestic environment within the film can hardly be categorized as culturally typical, but provides a means to explain a victim's seemingly inexplicable behavior such as hysteria. Although the issue of hysteria became outdated, gaslighting remains relevant. Noir obsesses not just with how America as an environment produces flawed people, but how environments in general impact the psyche. Noir tests the notion to its limits, toying to see what kind of environments it takes to push noir's poor heroes over the edge. Through psychoanalysis, noir provides the tools to continue examining culture and the individual psyche, rather than just providing a single cultural snapshot in time.

Noir's disordering environment most frequently manifests in the form of cities, which reveal cultural anxieties. Tina Lent's article, "The Dark Side of the Dream: The Image of Los Angeles in 
Film Noir," analyzes the representation of Los Angeles in noir more specifically, directly tying Los Angeles to noir's efforts in processing the failure of the American Dream. Los Angeles dramatically shifted in the public's perception from a promised land during the 1920's to a wasteland by the 1950's, which transformed it into a major target for criticism for the failure of the American Dream (Lent 329). Lent grants four primary reasons that Los Angeles came to draw so much public frustration, citing first its status as the newest major city on the farthest edge of the western frontier, thus framing the city as a bold symbol of promise so that its failure was much more sharply experienced (332). Second, she cites Los Angeles's status as a classical American city with a centralized downtown district (Lent 332). Third, she cites atypical features of Los Angeles that emphasized its failure, such as its horizontal suburban growth that, rather than producing small close communities, produced loneliness, frustration, and isolation (Lent 333). Finally, Lent references Los Angeles as a home to the film industry - many writers came to Los Angeles with big dreams only to find themselves without work, and their disillusionment lead them to write novels set in Los Angles discrediting the American Dream as a fraud (333).

Noir's emphasis on setting and use of actual American locales such as Los Angeles contributes to the verisimilitude of noir's otherwise outlandish stories. As a setting, Los Angeles takes a concrete and convincing visual form that many have had genuine experiences with and can relate to (Lent 335, 343). Lent claims that noir persuasively comments on American culture through its experience-based portrayals of Los Angeles. However, noir works much more effectively by treating Los Angeles and its cities as a symbol rather than presenting an accurate representation of them. While many have had concrete experiences with Los Angeles, many more have experienced Los Angeles through its portrayals in various media, so therefore noir reaches a broader audience by transforming Los Angeles into a grotesque symbol.

The more visceral the city's association with despair and entrapment, the more effectively noir can elicit a specific emotional response, regardless of the accuracy of these portrayals. Schrader succulently describes noir as "a nightmarish world of American mannerism that was by far more a creation than a reflection” (226). For instance, Raymond Chandler's short story "Red Wind" opens with a famous description of the opportunity for unpredictable violence that the Santa Ana winds seem to bring to Southern California. The line, "meek little wives feel the edge of the carving knife and study their husbands' necks," particularly creates a tangible image of evil within the "red winds." Although the Santa Ana winds do not actually provoke such violence, the description gives the audience a (false) sense of familiarity with the disorder, perhaps evoking outside violent impulses and memories, while legitimizing them through the connection to a genuine Californian characteristic. In this way, noir administers a cathartic release of frustrations formed by a variety of experiences. The physical city, as a tinted symbol, forges a bridge for deeper, repressed emotions to be expressed in the real and physical world presented on the screen (or page). The noir city is thus not a neutral environment, but a tinted living nightmare inherently designed to inhibit noir's heroes and tap into the darker emotions and impulses of the audience.

Noir's environments function as a psychological expression by bridging together reality, the unconscious, and creation. Rafter describes how "narratives seem to be crucial to our efforts to 
make sense of our lives. ... they form a bridge, with heavy traffic in both directions, between the "real world" and our imagination, between social experience and its interpretation" ("Why They Went Bad" 68, 69). The audience takes advantage of noir to toy with the real world, their unconscious, and their imagination. Noir allows the audience to process their real world struggles by outlining patterns and drawing connections between thoughts, just as a dream would. Christopher references Welles to say, "Orson Welles was correct: a film, above all else, is certainly a dream" (206). More specifically, noir functions as a nightmare. The film Gaslight demonstrates this function. The film warps the typical home environment into an inventively horrifying nightmare in order to deal with cultural fears about the implications of empowered and working - and perhaps even wealthy - women. The film dramatically expresses women's unconscious frustrations with accusations of hysteria and emotional exaggeration, and indulges the fears and emotions they were encouraged to repress and ignore. These separate issues tie together through the stylized, yet familiar, setting of the home.

Expressionist elements help create and dramatize the nightmarish depictions of noir's settings and characters. In his article, "Notes on Film Noir," Paul Schrader heavily emphasizes noir's focus on style over content. Film noir employs numerous creative stylistic tools such as first person narration, subjective camera shots, flashbacks, byzantine plots, extreme camera angles, chiaroscuro, and vertical lines, among many others. These stylistic elements help antagonize the environment and antagonists by striking fear within the viewer and establishing negative emotional associations with the settings and characters. Night of the Hunter, directed by German director Charles Laughton, adds to the fear surrounding the antagonist, Harry Powell, through the dramatic chiaroscuro that frames him throughout the film. Mulholland Drive, a neo noir film that strings together seemingly unrelated vignettes within a byzantine plot, relies on chiaroscuro and dramatic camera angles and lines in order to elicit the ambiguous emotions that tie the film together.

Because noir's style stands on an emotional base, it serves as an effective tool for cathartically eliciting strong emotional responses out of its audience, bringing unconscious emotions and issues to the surface. In doing so, noir encourages its audience to play psychoanalyst and toy with the psychologically hidden. Noir's stylistic focus on water especially reflects Freudian teachings. Freud's iceberg metaphor demonstrates how the greater part of a person's mind, memories, and motives remain hidden in the unconscious by referencing the way the greater part of an iceberg is concealed underwater. Noir seems to reference water's concealing property, inviting the audience to wonder what lurks beneath its surface. Night of the Hunter plays to this quality of water with its famous scene of the dead mother sitting at the bottom of the river with her hair flowing with the seaweed in the current. Other stylistic elements in noir serve similar concealing functions. For example, noir's darkness, in addition to its eerie nightmarish properties, also conceals. Complex chronology, also in addition to being nightmarish, shares a concealing property as well, muddling the plot and inviting the reader to play psychoanalyst and untangle its puzzle-in doing so, accessing that hidden chunk of the proverbial iceberg and thus exploring the unconscious. 
Noir's presentation as a dream invites dream analysis, which reveals the way the audience uses noir to process their problems and pasts. Freud asserts that we dream in order to deal with unsolved problems, which is a notion well reflected in the troubled noir protagonist who is "obsessed with the past, unable either to let go of it or to embrace it" (Osteen, "Someone Else's Nightmare" 23). Noir, like Freud's dream analysis, enables the audience to do both. In Out of the Past, Jeff attempts to repress rather than embrace memories of his past with Kathie and as a private investigator, until he can no longer ignore his history. He confesses the story to his girlfriend Ann, who forgives him, saying, "it's all past," and Jeff reveals an inability to let go of his past by replying, "maybe it isn't." As a traditional noir protagonist, Jeff represses his past, which inevitably explodes, forcing him to both embrace it, by eventually attempting to run away with Kathie, and simultaneously let go of it, by tragically dying at the end of the film. In a sense, noir tortures its protagonists in order to spare the audience the same pain - by indulging Jeff's past, noir allows its audience to vicariously indulge and acknowledge their own regrets and troubled pasts, and through Jeff's ultimate failure, noir permits the audience to let go of them.

Noir takes on a self-conflicting position as it both entertains a fascination with disorder and horror while simultaneously aiming to straighten out and make sense of this disorder. Noir's creative indulgence into horror aids the breakdown of repressed emotions and ideas and begins to examine and deal with them. However, noir encourages the audience to approach these narratives as an analyst - or psychoanalyst - as well. The narratives validate the audience's struggle, by allowing them to embrace, for example, Hank's poor decisions in A Simple Plan, but they also push the audience to understand their implications, the motivations that inspired them, and the ethics that surround them. Noir pushes the audience to approach the films with a critical mind. Thus, noir is both indulgently cathartic, yet constructively therapeutic as well. David Lynch's Mulholland Drive appears both completely incoherent, yet somehow wholly coherent at once, demonstrating the conflicting order and disorder that characterizes noir. The film pastes together dramatic, apparently unrelated storylines, scenes, and events into essential chaos. Yet, amidst the chaos, the scenes seem to fit together, held together by a unifying, ambivalent mood. Scenes reference each other, sprinkling connections between scenes and storylines throughout the film. Lynch heavily encourages viewers to draw their own conclusions and interpretations from the film, and critics have constructed wildly different theories about the film's meaning and plot. Just as the vague coherence of the film inspires creativity, the chaotic, ambivalent mood of noir as a whole inspires reflective and critical thinking that brings a sort of order and coherence to the genre.

Freud's dream analysis reveals the unifying relatable emotion of guilt at the core of all noir that permits its stylistic creativity. In "Someone Else's Nightmare," Osteen briefly outlines Freudian theory on dreams: "a dream consists of a manifest content (the particular images or situations within a dream) that camouflages latent content (the motivating emotions of memories)" (22). The manifest content of the dream is just the tip of the iceberg-so to speakinviting the audience to interpret the concealed motivating emotions of memories that make up the unconscious, meaningful, part of the dream. Osteen cites Earnest Hartmann who argued that "the most significant element in any dream is not its specific imagery but its dominant emotion" ("Someone Else's Nightmare” 44). Because noir narratives serve a Freudian purpose 
and are significant for their dominant emotion rather than specific details, they have the freedom to be creative - experimenting with wildly disordering environments to test the moral limits of characters - while ultimately still ringing true. Osteen argues that the most dominant emotion in noir is guilt: as he elegantly states, "What is guilt but an attachment to a past action that prompts need to relive and make it right?" ("Someone Else's Nightmare" 45). Despite noir's creativity, noir rings true broadly across audiences because its dominant emotion of guilt reads as relatable to many - particularly those feeling guilty and ashamed for failing to achieve the American Dream in a culture that blames the individual.

As "dreams" that allow the audience to process problems, noirs present creative examples of psychological and moral disorder for the audience to practice untangling, toying with the roles of the protagonist, disordering environment, and detective. As Fluck posits, "the central issue of film noir is the question of guilt" (382-3). Noir as a genre encourages the audience to explore a variety of "guilty" sources of disorder within society by casting a variety of different things, people, and forces within the role of the disordering environment.

Crime narratives present the ideal opportunity for examining guilt, and a closer look at the criminal heroes of noir reveals criminals significantly less in control of their circumstances and decisions than the heroes of crime narratives outside the noir genre. In "The Heroes of Crime Films," Rafter comments on the crime genre more broadly, establishing the genre's appeal through its heroes' concrete moral base - whether those morals are good or evil. "Good good guys" have appeal for their lawful, ethical, and constructive behavior, whereas "bad good guys" have appeal for their self-determinism and boldness to claim the freedom to do whatever they want (147). Rafter concludes that crime films have appeal because their value structures allow viewers to identify with both types of heroes and shuffle back and forth between "good" and "bad" values - in other words, crime films captivate because they allow viewers to toy with morality. However, noir deviates from typical crime narratives in that while there may be a handful of luckier, more respectable characters in noir, and although noir's protagonists are easy to empathize and sympathize with, they are hardly envied or admired. This distinguishes noir from the majority of crime narratives. Rafter references a category of protagonists that Carol Clover calls "victim heroes" (148). These protagonists double as ordinary people "thrust into a nightmarish predicament," and although the hero usually comes out on top, it is not without much suffering along the way (148). In contrast to the powerful criminal heroes of crime narratives outside noir, noir's heroes lack the power to take bold moral action - they play the victim, casting their environments as guilty.

Noir probes a wide variety of motives to explain the criminal behavior of noir's protagonists. Rafter outlines three basic criminal motives presented in crime films: environmental causes, psychopathy or mental illness, and aspirations for a better life. Bad biology and fundamental evil generally get rejected as explanations ("Why They Went Bad"). Fluck distinguishes three types of film noir, each with their own interpretation of the noir character, and each with their own statement on and understanding of crime. Fluck's three outlined figures of noir fit Freud's id, ego, and superego - the detective representing the superego who sees "crime [as] a moral text," and seeks to adhere to internalized principles of morality; the respectable citizen who 
approaches crime through the ego, seeing it as "an unforeseen effect of repression" in their efforts to achieve their goals; and finally the drifter, who represents the impulses of the id and acts on "unpredictable, accidental vagaries of impulse and mood" (402). Crime films serve as useful narratives through which the audience tries to understand what causes crime, its nature, and the motivations of the people behind it. Rafter contends that "most [crime films] do so opportunistically rather than in order to promote a specific interpretation" (69). Noir's creativity and variety comes from its significance as a process of questioning. That is, noir crime films do not intend to rationalize crime as much as nudge its audience to themselves take an active role in asking what causes crime themselves, thus promoting empathy for the criminal and audience.

Noir toys with tossing guilt on secondary characters, who are cast as additional aspects of the environment. Rafter draws the distinction between noir's "explanatory psychos," who are rounder characters whose crimes and disorder are accounted for, and noir's "cameo psychos," who are included "merely for local color" ("Why They Went Bad" 55). These "cameo psychos" are not afforded the same compassion and psychoanalytic explanation as the "explanatory psycho" protagonists. They simply serve as part of noir's environment, supporting the corruption of the protagonist - frequently as an antagonist. Noir goes beyond the protagonists past and physical environment to cast blame on a diversity of people in his environment: from greedy men (Night of the Hunter) to crazy men (Gaslight, Sunrise), to femme fatales (Double Indemnity, Kill Me Again, A Simple Plan). Again, the resulting object of blame is not necessarily significant, but the morally and psychologically ambiguous narrative pressures the audience to ask questions. The audience enjoys ambiguous criminological messages because there is significance in debating movies' meanings and moralities. Noir seeks to introduce psychoanalysis and promote critical thinking as tools.

Noir flirts with a segment of films that Rafter describes as existing without heroes. These crime films feature lead characters with no real redeeming traits, and the non-heroes of these hopelessly gloomy films aim to "erase the very idea of heroism" ("The Heroes of Crime Films" 160). Although audiences can appreciate crime as a tempting shortcut to the American Dream, these films claim "the dream has become empty, sleazy, and worthless, and crime has lost its glamour" ("The Heroes of Crime Films" 161). A Simple Plan seems to fit this description, as the film's unfortunate unfolding of events demonstrates how the America Dream comes nowhere near worth the dramatic loss of lives, relationships, and personal integrity Hank permits in his pursuit of money. Viewers accustomed to "bad good" heroes secretly cheer Hank on, only to be faced with the ugliness and senselessness of the murders and crimes committed. However, the fact that viewers cannot resist cheering Hank on and urging him to keep the money divulges his redeeming qualities. Unlike Jacob and Lou, Hank earnestly attempts to make sacrifices to succeed, to use foresight and think smartly. The film reveals that anyone - even smart, moral individuals - can make grave mistakes in their pursuit for success. While audiences celebrate typical crime films for their heroes' distinct control over their environments - whether for good moral reasons or for bad - they celebrate noir crime films for precisely the opposite reason. Audiences empathize with noir's heroes precisely because they have no control over their environments. At the end of the film, the audience hates Hank's decisions and circumstances, but does not necessarily hate him. 
In addition to tweaking the environment, noir sometimes explores the issue of guilt by challenging the audience to determine the protagonist of the narrative, and in so doing, examines the individualism associated with the American Dream. In narratives such as Kill Me Again, the protagonist of the film is not immediately clear. Both Jack Andrews, the private investigator, and Fay Forrester, the femme fatale, are victims of circumstance and take charge of their situations in order to hopefully overcome them. By initially concealing who holds the role of the protagonist and forcing the audience to guess, noir challenges the individualism intrinsic to the American Dream. Psychoanalysis points out the complex network of environmental influences and motivations that shape the actions taken by an individual. This information implies a need for a compassionate, complex sociological and institutional examination of society as an environment, since it must balance and serve a whole society of people whose unique motivations and needs translate into actions that also affect other people. Because noir's environments are more powerful than the individual, the individual must break rules in order to succeed, acting in their own self-interests, thus creating more difficult circumstances for another individual, and consequently sparking more rule-breaking and selfishness-noir's harmful environments self-perpetuate. While Jack ultimately acts more nobly and succeeds as the protagonist, the audience can still empathize with Fay, who simply acted out of a need to survive her circumstances. By confusing the audience about the identity of the protagonist, the film tricks the audience into empathizing with both - something American individualism does not do. The typical heroic narrative enforces American individualism by emphasizing and celebrating the success of only one individual - in altering this structure, the film criticizes the way individualism fails to properly support society as a whole.

Femme fatales such as Fay function especially usefully within noir narratives because they confuse the audience. On one hand, they serve as powerful, easy-to-empathize-with protagonists who take charge of difficult circumstances by any means necessary. But, on the other hand, they function as "crazy" and evil monsters who manipulate other characters and make up a piece of the disordering environment. For example, in the film Basic Instinct the brilliant and confident Catherine Tramelle appeals to the audience through her aggressive control over her environment - mimicking the way Rafter claims more traditional crime heroes appeal to the audience. At the same time, she plays such an evil and manipulating role within the story that the audience struggles to see her as human and empathize with her. Within a single narrative, such as the novel The Postman Always Rings Twice by James Cain, a femme fatale can play a wide range of roles. Cora Smith acts as a sex bomb, victim, sacrifice to the law, and a fearful girl in need of protection, among other roles (Christopher 198). Her flexibility challenges the audience to rethink their understanding of a woman's role.

Because women traditionally lack agency and remain extra vulnerable to circumstance, the audience struggles to decide how to react to powerful femme fatales. They appeal as heroes because they seem so in control, but disgust because they must go to "evil" measures to gain their power. Femme fatales reveal the ugly side of individualism - disempowered individuals require greed to achieve the American Dream. Modern perspectives shame the femme fatale as anti-feminist for catering to the male gaze and presenting such an ugly image of female success. 
The femme fatale is not necessarily an admirable figure because they must sacrifice their dignity and values in order to be successful - success is not necessarily dignified.

The film Double Indemnity shows the audience's awkward shift in exploring how to respond to the femme fatale. Phyllis plays a more subdued role than the typical femme fatale. Double Indemnity centers on the male perspective through its first person embedded narrative, voiceovers, and flashbacks. Despite Walter's patronizing, dismissive, and objectifying attitude towards Phyllis, her independence comes through to the audience. This irony may be a response to the women who, after taking over traditionally male jobs during WWII, were treated as incompetent by returning husbands who attempted to reclaim their jobs. The film points out that it is no longer feasible to ignore women's individuality. Walter treats Phyllis as a secondary character. However, although Walter prefers to pretend he has an individualistic hold on the entire murder plan, Phyllis brings an unpredictable element to the story that typical secondary characters do not. Double Indemnity challenges the idea of pursuing one's happiness with a complete disregard for others and mocks the notion of American individualism.

Born out of the psychological stress accompanying World War II, noir seeks to enable its audience to therapeutically work through their psychological disorder and to empower its audience to approach disorder with critical thinking. Nightmarish noir narratives frequently end poorly for their characters, who, trapped within their byzantine plots and old conflicts and habits, have no choice but to walk into their own doom. While noir cannot offer a solution for the failure of the American Dream, noir employs psychoanalysis to ensure its audience deals with conflicts and anxiety armed with the critical thinking skills necessary to tackle byzantine problems with good questions, creativity, and innovation. With that, noir displays a glimpse of optimism.

\section{ACKNOWLEDGEMENTS}

I would to express my gratitude to Dr. Ulrick Casimir for his support in the development and revision of this paper.

\section{REFERNCES}

A Simple Plan. Dir. Sam Raimi. Perf. Bill Paxton, Billy Bob Thornton, Bridget Fonda. Paramount Pictures, 1998.

Basic Instinct. Dir. Paul Verhoeven. Perf. Michael Douglas, Sharon Stone, George Dzundza, Jeanne Tripplehorn. Carolco Pictures, 1992.

Bronfen, Elisabeth. "Femme Fatale: Negotiations of Tragic Desire." New Literary History 35.1 (2004): 103-16. JSTOR. Web. 18 May 2014.

Cain, James M. The Postman Always Rings Twice. New York: Alfred A. Knopf, 1934. Print.

Chandler, Raymond. "Red Wind." Ed. Frank MacShane. Raymond Chandler: Stories and Early Novels. New York: Library of America, 1995 - 368-417. Print. 
Chandler, Raymond. The Big Sleep. New York: Alfred A. Knopf, 1939. Print.

Christopher, Nicholas. "The Dark Mirror: Sex, Dreams, and Psychoanalysis." Somewhere in the Night: Film Noir and the American City. New York: The Free Press, 1997. 187-222. Print.

Double Indemnity. Dir. Billy Wilder. Perf. Fred MacMurray, Barbara Stanwyck, Edward Robinson. Paramount Pictures, 1944.

Fluck, Winfried. "Crime, Guilt, and Subjectivity in "Film Noir."' American Studies 46.3 (2001): 379-408. JSTOR. Web. 23 Apr. 2014.

Gaslight. Dir. Thorold Dickinson. Perf. Anton Walbrook, Diana Wynyard. British National Films, 1940.

Goodis, David. "Professional Man." 1953. The Best American Noir of the Century. Ed. James Ellroy and Otto Penzler. Boston, NY: Houghton Mifflin Harcourt, 2010. 127-50. Print.

Kantor, MacKinlay. "Gun Crazy." 1940. The Best American Noir of the Century. Ed. James Ellroy. By Otto Penzler. New York: Houghton Mifflin Harcourt, 2010. N. pag. Print.

Kill Me Again. Dir. John Dahl. Perf. Val Kilmer, Joanne Whalley Michael Madsen. Propaganda Films, 1989.

Lent, Tina Olsin. "The Dark Side of the Dream: The Image of Los Angeles in Film Noir." Southern California Quarterly 69.4 (1987): 329-48. JSTOR. Web. 23 Apr. 2014.

Micale, Mark S. "The Decline Of Hysteria." Harvard Mental Health Letter 17.1 (2000): 4. Psychology and Behavioral Sciences Collection. Web. 23 Sept. 2014.

Mulholland Drive. Dir. David Lynch. Perf. Justin Theroux, Naomi Watts, Laura Harring, Ann Miller, Robert Forster. Universal Pictures, 2001. DVD.

Night of the Hunter. Dir. Charles Laughton. Perf. Robert Mitchum, Shelley Winters, Lillian Gish. Paul Gregory Productions, 1955.

Osteen, Mark. "'Someone Else's Nightmare": Exploring Noir Dreamscapes." Nightmare Alley: Film Noir and the American Dream. Baltimore: John Hopkins University Press, 2013. 19-45. Print.

Osteen, Mark. "Introduction: Film Noir and the American Dream." Nightmare Alley: Film Noir and the American Dream. Baltimore: John Hopkins University Press, 2013. 1-18. Print.

Out of the Past. Dir. Jacques Tourneur. Perf. Robert Mitchum, Jane Greer, Kirk Douglas, Rhonda Fleming. RKO Radio Pictures, 1947. DVD.

Rafter, Nicole. "The Heroes of Crime Films." Shots in the Mirror: Crime Films and Society. New York: Oxford University Press, 2000. 141-64. Print.

Rafter, Nicole. "Why They Went Bad: Criminology in Crime Films." Shots in the Mirror: Crime Films and Society. New York: Oxford University Press, 2000. 47-70. Print.

Schrader, Paul. "Notes on Film Noir." Film Genre Reader II. Ed. Barry Keith Grant. 2nd ed. Austin: University of Texas Press, 1995. 213-26. Print. 
Sunrise: A Song of Two Humans. Dir. F. W. Murnau. Perf. George O'Brien, Janet Gaynor, Margaret Livingston. Fox Film Corporation, 1927.

Yang, Amy. "Psychoanalysis and Detective Fiction: A Tale of Freud and Criminal Storytelling." Perspectives in Biology and Medicine 53.4 (2010): 594-604. Web. 23 Apr. 2014. 